\title{
Gerald Grace, spiritual capital, the CRDCE and ISCE
}

\section{Paddy Walsh}

\section{Introduction}

This chapter is in two halves. The first reflects on how Gerald Grace's seminal conception ${ }^{1}$ of 'spiritual capital', a variant of Bourdieu's generic concept, was formed in his analysis of fieldwork data, which he had gathered from in-depth interviews with 60 headteachers of Catholic secondary schools in poor innercity areas of London, Birmingham and Liverpool. The second half switches the focus to Gerald's centre of operations, generally known as 'CRDCE'.

The conception of 'spiritual capital' and CRDCE make a good match, the latter catalysing and disseminating the further theoretical, theological and practical developments of the former. Together, conception and Centre generate, and co-generate with other centres, a veritable mass of spiritual capital and thus help to achieve Gerald's goal of 'Catholic Education' as an established field of study. In the second section's portrayal of Gerald's CRDCE work, I have dared, as invited, to see myself as a personal witness. I have been at least loosely connected with it from its beginning in 1997 at the Institute of Education, University of London to its departure from there in 2016, and I have connected with it again in its more luxurious quarters at St Mary's University, in a different role. More generally, this chapter is built on many vignettes and personal experiences.

\section{Part I: Gerald Grace on spiritual capital}

In 2002, Gerald published Catholic School: Mission, Markets and Morality, to wide acclaim. Its concluding chapters (9 and 10) offer a fascinating account of the design and analysis of his marathon fieldwork, and how it led him to an understanding of the central role of a form of 'spiritual capital', defined as 'resources of faith and values derived from commitment to a religious tradition' (p. 236). Since the concept emerged from the fieldwork, we should attend to it first.

His single-handed engagement with 60 headteachers is justly celebrated for its ambition, but also for its fundamental rationale, methodological structure, courage, tenacity, the readability of its write-up, and, most of all, for its 
seriousness of purpose and import for the future of Catholic schools. It was also a source of relief for many readers, as it was for Gerald, that the headteachers and schools generally were still holding the Catholic line, and were indeed inspirationally committed to it - even if the future was found to be uncertain.

Ipso facto, the success of Gerald's research by interviews showcases and endorses the value of good fieldwork in complicated and developing social situations. It therefore had the benefit of addressing a Gerald complaint, namely that 'while a lively debate exists about the nature of spirituality and Catholicity in contemporary Catholic schooling, the amount of assertion and counter assertion is greater than the research evidence' (2002, p. 210). Moreover, it should be seen as creating a benchmark for future research - while also leaving little room for excuses should negligence allow school Catholicity to deteriorate as time goes on.

The latitude that qualitative research permits is gold in the hands of a wise researcher. Consider:

in an attempt to obtain further sources of evidence on these contested issues the sixty Catholic secondary school headteachers involved in the study were asked to give their considered professional judgements about the spirituality and Catholicity of their schools and students.

(2002, p. 214, my emphases)

The impression given here is of the researcher relaxing his usual controls, to see what more the heads might have to give. All the schools were 'inner city', but significant differences in other respects could be expected. The interview would probably be in the security of the particular head's own school and office. By all means then, let's have a proper conversation! Such flexibility is a major advantage of qualitative research, but it is also a tribute to Gerald's commitment, emotional intelligence and experience that many of the report's most interesting viewpoints emerged from such 'conversations'. So, regarding the central question of school 'Catholicity': ' $[\mathrm{t}]$ he majority of the headteachers looked for "outward signs of inward grace" among their students in the realm of relationships, behaviour, and involvement in good works' (2002, p. 215). There was prayer and liturgy too, but for most of these schools in a friendlier post-Vatican II way, with 'new forms of community, of worshipping together, and new ways of being family', and (another slightly reluctant-sounding headteacher), 'now we have to accept that Catholicity is a process of growing in understanding' (2002, p. 219).

That this new Catholicity might very well not include regular Sunday Mass is put down to 'weaknesses in the liturgical articulation of secondary schools and their feeder parishes' (2002, p. 221). A particularly strong statement seemed to speak for many heads:

...it is not that religion is ebbing out of Catholic schools - it is something within society itself. One could reverse the statement and say that the only 
hope that we have is the Catholic school... the role of the Catholic school is perhaps more important today than it ever was.

(2002, p. 223)

Others, too, observed that it is their Catholic school that is their young people's living church and parish - in regularly remarked contrast with their own Catholic schooldays. Gerald, however, holds his counsel on this feature of the 'new Catholicity'. Whereas, by contrast, his support and admiration for these 'front-line practitioners' of 'the preferential option for the poor' seep out from every reference.

In concluding this 2002 book, Gerald puts 'spiritual capital' centre-stage, as follows:

This study argues that the spiritual capital of the Catholic schooling system in England (and by implication elsewhere) is what has provided the dynamic drive of its mission in the past and helped it to preserve, in the main, its mission integrity in the challenges of the present. The renewal of its spiritual capital thus becomes the crucial question for the continuance of its distinctive mission in the future. This is a major conclusion of the research project.

(2002, p. 238)

He returned to spiritual capital in a 2010 article - presenting it now as an urgent priority for Catholic education across the world, and defining it more elaborately. 'It is a form of spirituality in which the whole of human life is viewed in terms of a relationship with God, in Jesus Christ and the saints, through the indwelling of the Holy Spirit', thus providing 'a transcendent awareness that can guide judgement and action in the mundane world', and as such, empowers educators to act not simply as professionals, but as 'professionals and witnesses'. It is something that is in urgent need of renewal for lay school leaders and teachers in an increasingly secular and materialist world, to help them to be Catholic witnesses for Christ and 'not simply professional deliverers of the knowledge and skills as required by the secular state and market' (p. 125). Also, it includes theological literacy in a pastorally effective form, but can be nicely distinguished from 'charisms', which refer to inspired new movements in the Church, compared to the humbler gift of personal empowerment and sustaining resource for everyday Christian leadership - yet still 'providing the animating force and dynamic power of Catholic schooling internationally' (p. 120).

However, his main concern in this article is 'formation', the process of the transmission of spiritual capital to the next generations of teachers in Catholic schools. Do we know what guidance is available on this, what should be available, what can be made available? We do know that the Catholicity built into teacher training in Catholic colleges, as experienced by most of Gerald's 
interviewees, is now much less available. The more flexible and dialogical forms of family religious practice bring further complications. Such considerations surely do suggest a deeper and better articulation, spiritual as well liturgical, between secondary schools and feeder parishes, with significant implications for initial and continuing clerical education, as well as for teacher education.

That in turn raises the question of the provision of such education. On this matter, Gerald engages with a recent article by the then Secretary of the Congregation for Catholic Education in Rome, Archbishop Michael Miller, CSB: 'To be effective bearers of the Church's educational tradition, laypersons who teach in Catholic schools need a religious formation that is equal to their... professional formation' and 'It is up to the ecclesial community to see to it that such formation is made available to all Catholic school educators.... [I]n this regard, Catholic universities have a special responsibility to assist Catholic schools' (2006, p. 5).

However, across the world of Catholic universities and colleges, Gerald could find very little evidence of genuinely formative programmes in the 45 chapters of the 2007 International Handbook of Catbolic Education, which he had recently co-edited, other than one 'original' programme in one American university. It is important, of course, to acknowledge that relevant philosophy and theology courses, 'fundamental theology for teachers' perhaps, can indeed be perspective-changing and, as such, a pastorally effective element in theological literacy. Excepting in seminaries, however, even these courses are likely to lack a sharp enough training edge for adequate 'learning how to': how to pray or care (in their widest senses), how to lead others in praying or caring, how to teach or show others how to pray or care. In 2013 Maria Riley O.P. and Kerry Danner-McDonald proposed 'a framework for the education of older youth, young adults and their educators' that would seem both to illustrate and bridge this gap impressively. Radical across its economic, business, social and ecological goals, it roots the programme in Christology, ecclesiology and liturgical planning, without which hearts would not be shaped (p. 28).

If not, or not yet, Catholic universities, then which other part of the 'ecclesial community' should we turn to? For Gerald, it is finally the responsibility of the various Conferences of Catholic Bishops internationally, but at that time he could find no sense of diocesan coordinated policies, or even evaluation studies in this area, leaving the prospects for 'formation' alarmingly laissez faire. He was reduced to a broad recommendation that the Conferences of Catholic Bishops internationally should give leadership in encouraging, (and even requiring), formation programmes to be created by various agencies. Those agencies, we might suppose, should surely include members of Teaching Orders with experience and success in transmitting their Orders' charisms to lay partners and successors; ${ }^{3}$ also those lay successors themselves, by now several generations deep, who had inherited responsibility for those charisms. The parallel task for diocesan schools will have its own typical challenges and resources, but much could be learnt from the experience, strategies and perseverance of Teaching Orders in this matter. 
An example of this is found in my mid-1990s case-study of a college-preparatory (14-18) Jesuit day school for boys, in a blue-collar (poor) corner of a north-eastern American city. I was encountering continuous formation and continuous regeneration of what I could later call 'spiritual capital': in its cross-curriculum focus on social justice, supportive networking with other American Jesuit schools, a thriving 'community service' programme, and an extraordinarily rich and varied retreat programme - which has to be my focus here.

Upper school 'Emmaus retreats' based on themes from the Spiritual Exercises of St. Ignatius were in groups of six for three days. The great majority of 'seniors', including the non-Catholics, would opt in, and staff, parents, and 'seniors' who'd already done one would volunteer as participant-leaders. Prayer 2000 was a current new development: a young Jesuit history teacher had proposed an adaptation of the Spiritual Exercises that would stretch them out over several months of 'normal life', and 25 seniors and 6 faculty had signed up. Also, annual faculty retreat and school subsidies for staff who wanted to do a private retreat were being seen as close to the core of staff development. And the young, lay principal was leading informal study-groups for new staff to consider the life and spirit of St. Ignatius. A final-year 'senior' questionnaire included 'their last retreat' in a series of in-school and out-of-school influences on their religious development, from which it emerged as a 'major' influence, along with 'parental lives and example', well ahead of the 'medium' influences of 'peer-group', 'Catholic schooling', and 'teachers' - not to mention 'minor' influences that sadly included 'their parish'. More than four out of five thought it at least 'probable' that their last retreat was not boring, taught them respect for the views of others, gave them a sense of self-worth, had brought them close to God at times, and had had a lasting influence on them. Remarkably, more than half were 'certain' of each of these things. (Walsh 2000)

Karl Rahner once began an address to a conference of Catholic teachers with the observation that teachers, like priests, are always concerned with the wholeperson, which therefore needs to include their own whole-selves. That is a profound remark about teacher formation (Rahner 1964).

My governor experience in two Catholic secondary schools has given me an impression of newly established and promising formation initiatives at diocesan and national levels. However, it seems wise also to repeat Gerald's ten-year-old bleak warning to bishops against inaction:

$\backslash$ hbox $\{/\} \backslash$ hbox $\{/\}$ Failure to [prioritise] this will result in the inevitable depletion of the historical deposit of spiritual capital in our schools and the gradual incorporation of Catholic schools into a secularised and marketised contemporary educational culture.

(Grace 2010, p. 124)

In recalling these vignettes, in the context of a discussion about Gerald's work on spiritual capital, it has made me convinced that 'formation' needs to be 
identified as the key to protecting this 'spiritual capital' over time from globalising, secularising and marketising forces. In the ongoing success of the CRDCE, Gerald has done much to support formation.

None of the preceding should be taken to deny that the Holy Spirit, the ultimate source of 'spiritual capital', is active in schools, including inner-city schools, those of other faiths and none - the policy and research implications of which for Catholic education deserve another paper.

\section{Part 2: Establishing the Centre for Research and Development in Catholic Education}

Meeting up: The modest room allocated to the CRDCE and Gerald when he joined the Institute of Education (IOE) in 1997 happened to be next to my modest room. We could hear the raised voices of each other's visitors and research students, often to realise the other side were also going on about Catholic education. I was indeed a natural ally for my new neighbour. I had happily participated in Catholic education as pupil, student, teacher, parent and governor, had spoken and written philosophically-theologically about it, and had supervised many masters and doctoral students working in faith education. Gradually, his research base and bold vision drew me in, though my own general work responsibilities meant my actual service and participation had to be 'occasional' and 'light', e.g. standing in for him to welcome visitors from abroad and supporting the Centre's seminars and debates. That is not to say, however, that I am short of revealing personal memories. Four revealing 'case studies' are summed up here.

\section{Gerald, schools and teachers}

Once when indisposed, Gerald asked me to take over a whole-staff evening inservice training session at a prominent Catholic school, using the formidable structure and materials he had developed for such occasions, which worked very well. But most striking was Gerald's determination to stay in touch with Catholic schools, in one of which he had started his own career and to many of which his recent research had taken him back. Similarly eloquent was his engagement in the new Continuing Professional Development courses of the time for aspiring school leaders. He contrived an invitation to offer extra lectures and seminars for the Catholic, and other interested, aspirants.

\section{Gerald and the teaching profession}

In 2011, I was his emergency stand-in at the annual conference of the Catholic Association of Teachers, Schools and Colleges (CATSC), an important event attended mostly by senior teachers and diocesan advisers catching up with each other, listening to distinguished speakers, enjoying opportunities to pray and to 
attend Mass together, and in all these ways renewing their commitment to Catholic education for another year. The point here is that if Gerald could not be there, he needed to be visibly represented - I was to be careful to explain that I was deputising for him and was charged with giving him a later account. This was reaffirming his relationship with the profession nationally, with the dioceses of the northern heartlands of English Catholicism where that year's conference was being held, as well as with London and the south, thus nicely complementing his relationship with teachers in their schools and classrooms surrounded by students.

\section{Teaching Orders, etiquette and history}

CRDCE had to pay most of its own way. A prestigious Leverhulme Fellowship (1997-2000) allowed Gerald to conduct and write up his inner-city research, and he took only personal expenses from the budget. As regards its own secretarial and scholarly work, creative fund-raising was immediately needed. Appeals to various bodies, and repeated as necessary in later years, had the overall effect that the Centre was kept going very largely by donations from over thirty Religious Congregations, female and male. There was also a side-effect. Because the original appeals to Orders had requested a representation of their founder to be displayed in the office, Gerald's desk would soon be surrounded by great saints - to the interest, mystification, delight, or consternation of new visitors, including IOE colleagues.

Were these representations, perhaps, aids to prayer? Though less pious, the answer I got was one that the founders and the Orders themselves would probably find more fitting. As originally an historian, he could only be affronted by the ignorance and condescension of contemporary educationists regarding the debt owed to Religious Orders down the ages. Having these visual aids handy in his office would encourage conversation on just that theme. Later, of course, he would combat this prejudice on a wider front by inviting and facilitating many contributions to the international journal from religious women and men.

\section{Looking to the future}

Gerald has definitely accepted and wanted both the CRDCE and the journal ISCE to flourish long after he ceased to be actively involved. ${ }^{4}$ Succession planning has always been an important priority for the CRDCE, both during its time at the IOE and more recently at St Mary's.

\section{CRDCE at the IOE}

The arrangement between Gerald and Director Peter Mortimore was far more than a business deal. There were educational and cultural advantages that were also mutual and, for sure, also anticipated by both Gerald and Peter. The 
challenge offered to more dogmatic forms of secularism would be one. Courteous though it would be with Gerald in charge, the arrival and presence of an education firmly and officially rooted in Catholicism would challenge some secular assumptions and prejudices and could attract some opposition in the IOE. ${ }^{5}$ In return, the CRDCE could then expect a better-informed secular questioning of its own assumptions and prejudices. Such ongoing arguments are of course proper in a university institution. ${ }^{6}$ In this case, the collective stores of knowledge and experiences of Catholic schools in the IOE staff and student bodies could be expected to keep arguments civil - at the very least. And then there would be so much that was common, nearly or actually, ${ }^{7}$ to talk about.

To raise the profile of the CRDCE, Gerald made astute use of well-presented notices and pithy statements, using the outside of his office door as a noticeboard until proper ones were provided. I can recall a ringing affirmation of the primacy of conscience from the young Fr. Joseph Ratzinger (later to become Pope Benedict $\mathrm{XVI}$ ), jostling with enthusiastic references to then controversial Liberation Theology. A liberal Catholic and a committed socialist! This is the place, perhaps, to recall Gerald's frequent references to the advice Jesus gave to his disciples as he sent them out on their mission, to be 'as innocent as doves and as wise as serpents' (Matt.10: 26-33). The mixture of humour and gravity that typically accompanies the reference reminds one of the 'call' he has sometimes associated with his project. In fact, however, as an internationally experienced, clearly creative, and famously hard-working professor and leader, with a relaxed demeanour, genuine sociability and a good heart, he was always going to be at home in the IOE, given that it too has a generally good heart. Most of his work was for CRDCE from his Brighton home, of which some, alongside many other inputs, would be fed into the life of the IOE. As well as reconnecting with old friends like Basil Bernstein, he made new friends collaborating and supporting younger educational sociologists, religious studies tutors, school improvement researchers, and, no doubt, many others.

Contributions to the IOE's public occasions included a well-attended and much appreciated Inaugural Lecture and deft chairing of the Inaugural of his great friend, Terry McLaughlin. Most memorable, however, was his astonishingly fierce lambasting of invited guest speaker Chief Inspector Chris Woodhead in the IOE's largest auditorium, the Logan Hall. It was for his collaboration in the government's unpicking of the historically hard-won university role in teacher education and, as such, a particularly wretched abuse of his own noble office. Hospitable and charitable this attack was not, but few were as alive as Gerald to the threads that would consolidate this reversal with a de-culturing both of teaching itself, pedagogy, and what would be taught, the curriculum - and a 'marketisation' of all three.

By no means least, Gerald became an important rallying point for Catholic staff and students at the Institute, advertising in-house Masses, rustling up the Catholics he'd come to know, also advertising talks and services in the Gower Street Catholic Chaplaincy - of which he was a sterling supporter. He remains an honorary visiting professor at the IOE. 


\section{CRDCE achievements}

What was the unfolding CRDCE agenda and how did it fare in practice? Between 1997 and 2006 the focus had been national: INSET materials and consultations; a good 'professional focus' series of ten short books (around 30 pages each), offering Catholic perspectives on some significant curriculum or policy issue - and the tenth including a small fieldwork study; and Gerald was also available for media consultations and for a Catholic contribution to important new government programmes for aspiring headteachers.

In September 2016, he used a Keynote Address (with handout) at a Heythrop Conference to present an audit of CRDCE's two later phases, both international. The first had centred on the Handbook of Catholic Education (IHCE), five years in the making and completed in 2007, two volumes containing 45 chapters from $30+$ countries across all continents. Professors Gerald Grace and Joseph O'Keefe SJ of Boston College had organised and edited it, and in its final chapter had identified its ten main themes and challenges. He noted a strong focus on empirical research studies, but a neglect of philosophers, theologians and 'new thinking writers'. Its principal limitation, however, was to be static of its very nature in sharp contrast to the 'keeping-up' dynamic of ISCE. The creation of ISCE in 2009 'marked a key moment in the international profile of the CRDCE'.

The final part of the Address was an eloquent rallying call to the 'profound and fundamental purposes' of Catholic Education Studies, so we can show by research evidence that our institutions 'do practice servant leadership, do use a pedagogy of dialogue (and not of "indoctrination"), do serve the poor and deprived, and are in open relationship with the local community' and 'are sensitive to the existence of other faiths and those of no faith in our schools'.

\section{The CRDCE at St Mary's University, Twickenham (from 2016 onwards)}

After some years of negotiation, the CRDCE moved to a new home, in St Mary's University, Twickenham. The move began in auspicious style with Gerald's Inaugural Professorial Lecture, The Achievements of the Past and the Challenges for the Future. Its bold opening sentence, 'The academic and professional field of Catholic Education Studies has now achieved international recognition', reassured all present that the professor was settling in well at St Mary's. His strategy was to identify and honour St Mary's past and present achievements in Catholic education with a view to inspiring - and preparing its leadership for the major challenges he would present at the end. For the purposes of this account, that order will be reversed.

Three expensive challenges, but apt for a new university with a Catholic heritage: 
1 To establish a Chair of Catholic Education Studies; a major financial challenge, but a development priority.

2 To build a Doctoral Programme in Catholic Education to attract MA completers to more advanced scholarship and research, but requiring extra supervisor staffing.

3 To plan capacity for large-scale studies and longitudinal investigations, requiring resourcefulness in competing for major research funding.

Gerald had skilfully pointed out that St Mary's heritage provided a solid foundation for such investments. Throughout its Vincentian period (19251992), it had been a leading provider of Catholic teacher education, indeed across the whole of the UK and Northern Ireland for much of St Mary's time in charge. A distinguished Vincentian educationist, Fr Joe McCann $\mathrm{CM}$, had recently described it as offering its teachers-to-be 'a spirituality of education that took account of the reconciling mission of Christians to participate in the invitation of God, the Church and its people [to the service of] the poor, the ignorant, the outcast, the stranger, the sick and the vulnerable' (McCann 2014, p. 104). That resonated strongly with Gerald's own interviews with inner-city heads and his reflective realisation of 'spiritual capital' as the resource on which they drew.

Another part of the heritage was the success of the MA in Catholic School Leadership course, running since 1997. Over 150 students had completed it, the great majority by part-time study, and another 150 were currently enrolled. Its founder and first course leader had recently described it as 'a unique M-Level programme' that combined 'a Catholic philosophy of education with the principles and practice of effective school leadership' and, through its integrated nature, encouraged participants to develop 'local workplace theology as they engaged, in balanced, subtle and creative ways, in the process of relating the Gospel to contemporary contexts, questions and perspectives' (Sullivan et al. 2015, p. 32). The course is a genuine runaway success story.

A third asset proceeded from the second, namely the 150 MA dissertations seen as a counter-cultural library resource. No other Catholic university in Europe held a library of such systematic scholarship and fieldwork inquiries in the field of Catholic education. Having conducted a 'preliminary content analysis', Gerald presented a starting list of 26 'themes for further enquiry', and with a quite different focus from MA/M.Ed. dissertations in secular universities, Catholic concepts of education and leadership being 'distinctly different'.

Gerald's presentation of his case was a tour-de-force, and as the then current external examiner to the MA in question (as he himself had been many years earlier), and also having taught in St. Mary's for eight years of the Vincentian period, I knew none of it was far-fetched. But it had needed his touch to expose its potential as a base and resource for a doctoral school. 


\section{Concluding observations: Gerald the scholar and editor}

It is only fitting to end this chapter by recognising that over the past 25 years Gerald has been an active scholar. In 2020, the British Journal of Sociology of Education (BJSE) published his fine article 'Taking Religion Seriously in the Sociology of Education: Going Beyond the Secular Paradigm'. It is a stinging critique of the disappearance of religion from sociology's sight and it is so well and clearly done that it could jolt the field into reconfiguring itself. There were welcome new perspectives on the complex interactions of class, race and gender in education and other contexts, but Alistair Campbell's 'we don't do God' would sum up its attitude to religion. Gerald speaks here of a fundamentalist secularism, which also forgets that fundamentalism represents only falsehood is its tendency to present Paulo Freire as a secular radical, ignoring the fact that he was a believing, practising member of the Catholic Church - which, however, he would like to be more deeply committed to the poor. In similar vein, Gustave Gutierrez's foundational texts of Liberation Theology are neglected, although they inspire students, from Latin America to Africa, Asia, Europe and North America, to believe in the role of religion in contemporary society. The BJSE and its readers are asked to recall and emulate how the founders, Marx, Durkheim and Weber, in their different ways and regardless of their own religious beliefs, all took the causal powers of religion very seriously. This accessible paper has something for every education professional.

Sometime after Gerald had settled in at St. Mary's and had renewed his routine of coming up from Brighton twice a week, I was invited to help him out at fortnightly intervals. This allowed me some close-quarter observation of a foundation editor of a now established and prestigious journal at work. My main role was to assist him with his items of correspondence and to ensure they were properly dispatched. Typically they contained searching and constructive comments on draft papers, proposals to potential contributors, matters of policy. The correspondents ranged from university presidents and archbishops to hopeful young doctoral students.

If I must keep what I learnt or relearnt from working with Gerald down to a couple of sentences it would be as follows: Gerald is hugely proactive, forging ahead much more than catching up, and therefore marvellously productive. He is dedicated and disciplined, and urbanely so. He is bold in his approach to senior figures, but goes the extra mile with juniors. When he has to say no, he does it gently - and blames the editorial board! He is fun and Christian in (nearly) all things.

\section{Notes}

1 Following the convention of 'conception' as a particular interpretation of a more general and widely used 'concept'.

2 CRDCE stands for the 'Centre for Research and Development in Catholic Education'. 
3 I was also aware that for many excellent people the Catholic dimension of their schools had diminished or spoilt their education.

4 I recall that a 'Brief Confidential Minute' of a late 2012 'working party' to consider 'The Future of the Centre (including its work for the International Journal)' captures Gerald at his illuminating and prophetic best, identifying two scenarios:

1. If Gerald were 'rendered unable to continue' as Director of the Centre and editor of the Journal, the other three of us present, our two Fellows and myself, would, to the best of our collective abilities, ensure the survival of the Centre and the International Journal by keeping both going in the interim and by ensuring the eventual appointment of a new Director. Keeping things going would be assisted by secretary Matt Urmenyi's expert knowledge of the bedded-down routines of the Centre and the Journal, and by Gerald's policy as editor of the Journal to maintain a stockpile of acceptable papers for several issues ahead. 2). Options through and beyond Gerald's unforced retirement were limited by the improbability of finding a suitable replacement who would also be willing to work 'pro bono'. In Gerald's estimate, his successor would require a salary at Senior Lecturer level for some substantial number of years - to be added to the present running Centre expenses - whether at the IOE or elsewhere. But it was not yet time to hold formal discussions with other institutions.

Gerald emerges as definitely wanting a Centre and Journal beyond his stewardship, while not planning it in a way that would tie his successors' hands.

5 This was not to be feared, because as Harvey Cox noted, 'If freedom once required a secular critique of religion, it can also require a religious critique of the secular' (Cox, 1984, pp. 170-171).

6 It helped that the IOE already had a Jewish education Centre, run by Dr. Josephine Cairns. Not much later, it would also have a thriving Centre for Islamic education led by Professor Farid Panjwani. These Centres worked well together.

7 This 'same but different' dialectic is the legacy of the 1944 Butler Act that guaranteed public funding of faith schools - a legacy arguably much weakened now by the combination of academisation and free schools.

\section{References}

Cox, H. (1984). Religion in the Secular City: Toward a Postmodern Theology. New York: Simon \& Schuster.

Grace, G (2002). Catholic Schools, Mission, Markets and Morality. Abingdon, Oxon and New York: RoutledgeFalmer.

Grace, G (2010). Renewing spiritual capital: an urgent priority for the future of Catholic education internationally. ISCE 2:2, pp. 117-128.

Grace, G (2020). Taking religions seriously in the sociology of education: going beyond the secular paradigm. British Journal of Sociology of Education 41:6, pp. 859-869.

McCann, J, CM, (2014). Contributions of the Vincentians to Catholic education in Ireland and England. ISCE 6:1, pp. 91-107. doi:10.1080/19422539.2013.869956

Miller, M (2006). The Holy See's Teaching on Catholic Schools. Manchester, NH: Sophia Institute Press.

Rahner, K, SJ (1964). The Christian Teacher: Freedom and Constraint. In Mission and Grace, Vol 2. London and New York: Sheed and Ward, pp. 116-144.

Riley, M and Danner-McDonald, K (2013). Seeing the world anew: educating for a just and sustainable future: new perspectives for a Catholic curriculum. ISCE 5:1, pp. 23-35. 
Sullivan, J, Murphy, A and Fincham, D. (2015). The story of an educational innovation: the MA in Catholic School Leadership at St Mary's University College, Twickenham, 1997-2013. Principles, pedagogy and research studies. ISCE 7:1, pp. 28-45.

Walsh, P (2000). New Wine in Renewed Wineskins: A Jesuit School Now. In Cairns J, Gardner R and Lawton D (eds.) Values and the Curriculum, London and Portland: Woburn Press, pp. 134-139. 